Received 20.01.2018 Reviewed 26.03.2018 Accepted 10.04.2018

A-study design

B-data collection

C-statistical analysis

D-data interpretation

E-manuscript preparation

F-literature search

\section{Hydrological drought index based on reservoir capacity - Case study of Batujai dam in Lombok Island, West Nusa Tenggara, Indonesia}

\footnotetext{
1) University of Mataram, Jl. Majapahit No.62,83125 Mataram, Indonesia; e-mail: yasaiwayan68@unram.ac.id

2) Brawijaya University, Indonesia; e-mail: mbisri@ub.ac.id, mochsholichin67@ub.ac.id, uandawayanti@ub.ac.id
}

For citation: Yasa I W., Bisri M., Sholichin M., Andawayanti U. 2018. Hydrological drought index based on reservoir capacity - Case study of Batujai dam in Lombok Island, West Nusa Tenggara, Indonesia. Journal of Water and Land Development. No. 38 p. 155-162. DOI: 10.2478/jwld-2018-0052.

\begin{abstract}
Hydrological drought index analysis has been widely developed and applied for the development of water resources. The island of Lombok, which is largely a dry land, requires a significant hydrological drought index to be sourced from measurable data analysis. This research focused aims to obtain hydrological drought index in Lombok Island using the capacity change of reservoir. The analysis includes reservoir data especially in the event of El-Nino. The main parameters analysed in this work are data homogeneity, decrease line of reservoir volume, increase in the line of reservoir volume, reservoir volume deficit, and hydrological drought index $(R D I)$. The basic equation uses the water balance in the reservoir, which is the inflow-outflow and change of reservoir. The results of the analysis show that in the event of El-Nino, the drought hydrological index indicates different levels depending upon the water level of the reservoir. The criteria for the drought level are as follows: weak $R D I=$ from -0.46 to -0.01 at an reservoir elevation of 90.88 to $92.33 \mathrm{~m}$ a.s.1, moderate $R D I$ : from -0.59 to -0.46 at water level of reservoir from 90.27 to $90.88 \mathrm{~m}$ a.s.l, sever $R D I$ : from -0.80 to -0.59 at water level of reservoir from 88.83 to $90.27 \mathrm{~m}$ a.s.l. and very severe $R D I$ : from -0.89 to -0.80 at water level of water reservoir 87.78-88.83 m a.s.l. The duration of drought was 9 months, i.e., from February to November.
\end{abstract}

Key words: drought, El-Nino, hydrological drought index, inflow, outflow, reservoir

\section{INTRODUCTION}

Drought occurs almost all over the world, affecting all sectors of life, agriculture, health, social, and economic and industrial sectors. A drought is an event where there has been an extreme decline in the number of water sources [PANAGIOTIS et al. 2012]. A decrease in water quantity may result due to a decrease in the river flow, reservoir and lake volume, groundwater level, and soil moisture. It is a natural phenomenon associated with dry periods of long-term water supply deficits [TALLAKSEN, VAN LANEN 2004]. It is a natural disaster caused by the expected decrease in the precipitation, which is not sufficient for human and environmental needs [TABARI et al. 2013]. The occurrence of drought may be more often due to the below normal quantity of precipitation [PETER et al. 2006]. Low flow is caused by the lack of water in one or more components of the hydrological cycle. This happens when the water available from a system is insufficient to supply to at least one of the biological, economic, and social water requirements for a long period of time [TSAKIRIS et al. 2007]. Low flow is determined by an annual flow cycle, which is based 
on the regional climates and occurs in all seasonal zones that are predominantly affected by human (anthropogenic) factors [LOON, LANEN 2012].

The types of drought vary depending on the factors that affect the cycle of water availability, such as climatological, agricultural, hydrological, and socioeconomic [FLEIG 2004; TALLAKSEN, LANEN 2004; YOUNG 2010]. Among these droughts, the hydrological drought component is very significant because it is used for analysing the fulfilment of water needs of industries, domestic water demand, and water required for the generation of hydroelectric power [VASILIADES et al. 2013]. Hydrologic droughts have a very wide impact on the availability of surface water, degradation of water quality, the limited supply of irrigation water, and affecting social activities of the community during drought [MISHRA, SINGH 2010].

Various methods have been proposed to analyse the characteristics of the hydrological drought index. YEVJEVICH [1967] proposed the statistic-based run method for analysing drought. While SHAFER and DEZMAN [1983] analysed drought with the surface water availability index ( $S W S I)$ in the form of snow, rain, river flow, and reservoir water. The severity of the drought is defined as the ratio between flow volume deficit and volume of normal flow conditions or the ratio of maximum deficit duration to normal flow duration conditions [PANDEY et al. 2008]. DENGHUA et al. [2013] modified the Palmer drought severity index based on a water-based hydrological distribution simulation. The parameter of water balance used is the water contained in the surface layer of soil in the form of moisture/humidity of the soil with water that is measured.

Analysing hydrological drought index based on an elevation in the surface water level has been used in various countries in the form of simple investigation using various methods, such as percentage of storage capacity, standardized reservoir index, and reservoir deficiency index. The common hydrological indicators used in the drought index analysis are reservoir volume, water flow, and groundwater availability [PALMER 1965]. CALVER [2011] stated the management of drought in the UK is using the status of water conditions in rivers, reservoirs, lakes, groundwater, and soil moisture. The drought index is presented on the map of drought status however, it cannot describe the duration of drought.

YAN et al. [2013] modified the Palmer drought index by simulating the hydrological distribution using the water balance between the availability of water in the soil layer and flow. The results of the water balance were further used to modify the Palmer drought index. The amount of deficit value is a deviation in water shortage with threshold and duration is the entire duration of water shortage. The magnitude of drought index values is obtained based on water shortages versus wide watersheds. WAMBUA et al. [2015] proposed a hydrological drought index using a modified Gumbel method stream in upstream of Tana watershed. LIU et al. [2016] predicted drought in North-West China using standard flow indices, and HARO et al. [2014] analysed the annual drought risk assessment in the reservoir regulation system applied to the river system. ZHANG et al. [2014] conducted hydrological drought analysis based on the regulation of two reservoirs in the upper valley of the Chinese Huahie River. The analysis was performed using correlation analysis and comparison of stream flow drought index $(S D I)$.

This study aims to develop a hydrological drought index at the time of El-Nino phenomenon by utilizing a decrease in the capacity of the reservoir. The development of this model will obtain actual conditions of drought in each period because it is sourced from the quantity of measured water in the reservoir. Thus, while predicting the drought, the region will be easily carried out on the basis of the decrease in the water level of the reservoir for each period. Drought index is needed in planning and management of water resources as an effort to anticipate drought and can be used to predict the availability of irrigation water requirements [KHEZAZNA et al. 2017; ŁABĘDZKI, BĄK 2017].

\section{MATERIAL AND METHODS}

\section{STUDY AREA}

This research was conducted in Batujai dam located in Central Lombok Regency West Nusa Tenggara Province, Indonesia located at $116^{\circ} 15^{\prime} 29^{\prime \prime}$ $\mathrm{E}$ and $8^{\circ} 44^{\prime} 8$ " S. Lombok is one of the islands in Eastern Indonesia (Fig. 1), which is a dry land area with very low rainfall intensity. Every year, there is drought due to which the available water source becomes dry. Batujai Reservoir is built on Penujak River, which flows from the slopes of Kundo and meets into the Lombok Strait with a river length of $54 \mathrm{~km}$ and a catchment area of $169 \mathrm{~km}^{2}$. Penujak River has a large difference in river flow between dry and wet seasons. In the rainy season, the average monthly discharge can reach tens of cubic meters per second, whereas in the dry season the average monthly discharge can reach $0.1 \mathrm{~m}^{3} \cdot \mathrm{s}^{-1}$ or even less. The gross reservoir capacity $25.05 \cdot 10^{6} \mathrm{~m}^{3}$, effective capacity reaches $23.502 \cdot 10^{6} \mathrm{~m}^{3}$, and minimum capacity reaches $1.4 \cdot 10^{6} \mathrm{~m}^{3}$.

The data used for the analysis are reservoir daily water level $(H)$, daily change storage $(\Delta s)$, daily inflow $(I)$, and daily outflow $(O)$. Data based on the changes in storage, inflow, and outflow were obtained from daily measurements. All these data are real-time that were measured every day from 1982 to 2016. 


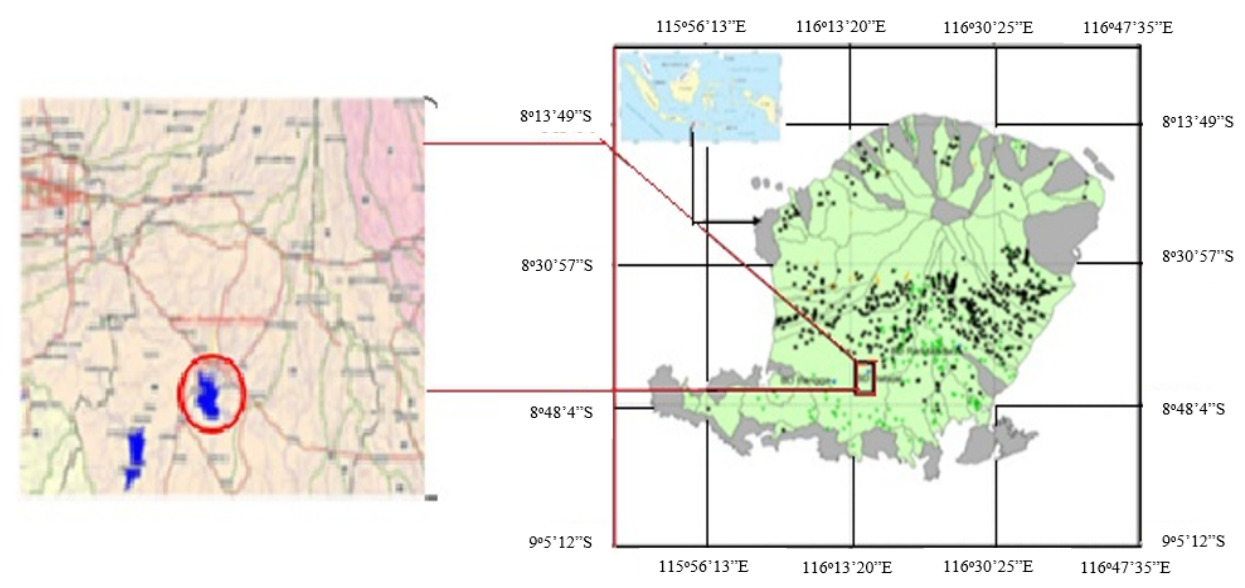

Fig. 1. Location map of the study area; source: own elaboration

\section{IDENTIFICATION OF EL-NINO OCCURRENCE}

Based on oceanic Nino index $(O N I)$, the phenomenon of El-Nino and La-Nina has been started since 1950 until 2017. It was identified that four types of El-Nino intensity were existed, which include weak, moderate, strong, and very strong. The El-Nino type index is based on the mean sea surface temperature (SST) [NOAA 2017]. The data used in the hydrological drought index analysis in the Batujai dam is data on the occurrence of El-Nino, as shown in Table 1.

Table 1. Recorded El-Nino events during 1950-2017

\begin{tabular}{|c|c|c|c|}
\hline \multicolumn{4}{|c|}{ El-Nino type } \\
\hline weak & moderate & strong & very strong \\
\hline $1994-1995$ & $1991-1992$ & $1972-1973$ & $1982-1983$ \\
$2004-2005$ & $2002-2003$ & & $1997-1998$ \\
$2006-2007$ & $2009-2010$ & & $2015-2016$ \\
\hline
\end{tabular}

Source: NOAA [2017].

\section{TESTING THE HOMOGENEITY OF DATA}

Homogeneity tests are intended to provide confidence that the set of data used in the analysis comes from a population that has uniformity. The homogeneity of data was tested using $F$-test. The testing process and formula used for testing the homogeneity of the data group variance are as follows:

$$
\begin{gathered}
F=\frac{S_{x}^{2}}{S_{y}^{2}} \\
S_{x}^{2}=\sqrt{\frac{n \sum X^{2}-\left(\sum X\right)^{2}}{n(n-1)}} \\
S_{y}^{2}=\sqrt{\frac{n \sum Y^{2}-\left(\sum Y\right)^{2}}{n(n-1)}}
\end{gathered}
$$

Where: $F=F$-test, $n=$ period of data record (years), $X=$ variable $X, Y=$ variable $Y, S_{\mathrm{x}}=$ variable of variance $X$, and $S_{\mathrm{y}}=$ variable of variance $Y$.

\section{THE DECREASING LINE OF RESERVOIR CAPACITY}

During El-Nino, there was a change in the water cycle in the reservoir. At that time, the inflow component was smaller than the outflow component. The outflow component includes water coming out to supply the increasing need for irrigation water, evaporation, and seepage. The decrease in the water volume of the reservoir does not occur suddenly but gradually and is reflected by the line of the volume decreasing. This recession may attain the maximum drop limit that reaches the dead storage depending on the length of the El-Nino period. The decrease in reservoir volume at the time of El-Nino is formulated into the exponential equation of the relation between the time and volume of the reservoir.

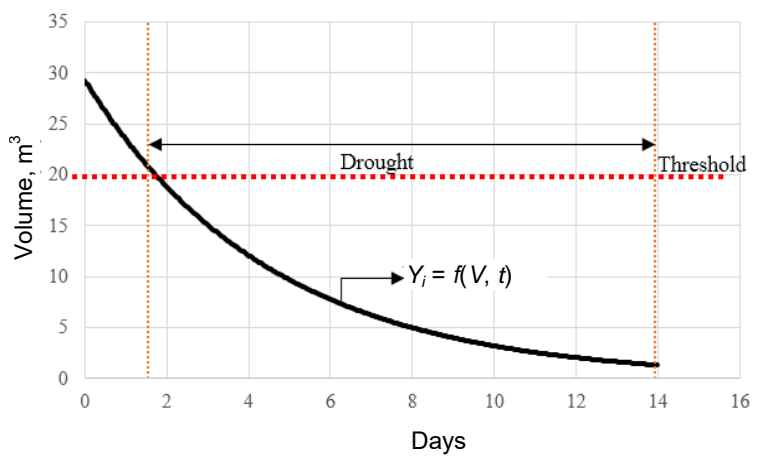

Fig. 2. Decrease in reservoir capacity; source: own elaboration

\section{INCREASE LINE IN RESERVOIR CAPACITY}

The increase in the line showing the reservoir capacity indicates that the El-Nino phenomenon ends and the process of recharging the reservoir begins to occur. The recharge process is influenced by the river inflow and precipitation. The increasing line shape 


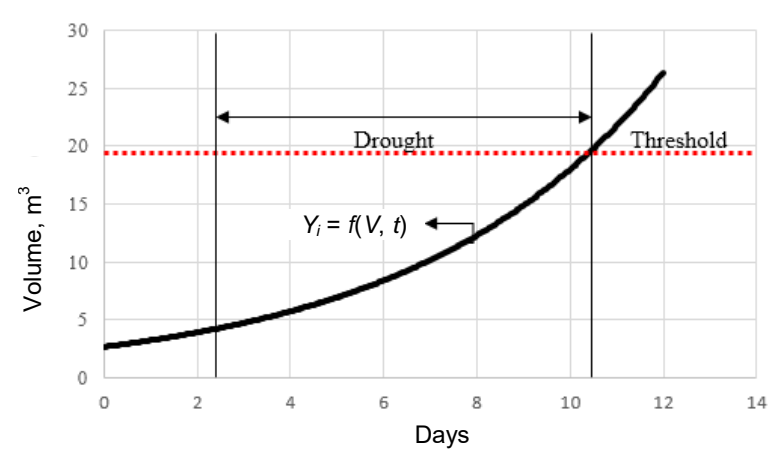

Fig. 3. Increase in of reservoir capacity; source: own elaboration

may help to improve the reservoir outflow regulation process at the end of the El-Nino event. Additionally, it will be able to predict the recharge time of the effective volume.

\section{THRESHOLD LINE}

The threshold value was used to identify the drought characteristics. In this research, a constant threshold was in the analysis. The threshold level was set and used to determine:

- threshold $(X \mathrm{o})$, which is the limit value determined based on analytical requirements [FLEIG et al. 2006];

- in this model, the threshold uses an effective volume reservoir.

The dashed line in Figure 4 shows the specified threshold volume. Furthermore, throughout the recording period, the volume of the existing reservoir is statistically identified as the value of the discharge that falls below the threshold. The recording period in which the reservoir volume is below the threshold is called a water deficit that has the potential to produce drought. The daily reservoir volume, which is below the threshold, is expressed as a discharge deficit condition.

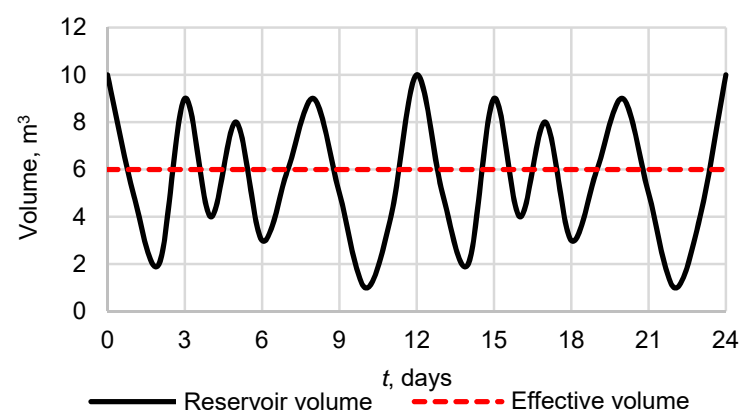

Fig. 4. Determining the threshold; source: own elaboration

\section{DURATION AND DEFICIT OF DROUGHT}

Drought characteristics are needed to identify the hydrological drought in a region by determining the time of the initial and end drought, drought duration, drought deficit volume $\left(V_{d}\right)$, and minimum volume
$\left(V_{\min }\right)$ during the occurrence of hydrological drought [FLEIG 2004; HISDAL et al. 2004]. The duration and volume of the hydrological drought deficit are determined by identifying the volume of daily reservoirs that are below the threshold. When the reservoir volume falls below the threshold, the drought begins (onset date) and if the volume of the reservoir rises to the threshold, the drought event terminates. Duration is the length of days from the start to end date of the drought. The difference between accumulated volume thresholds below the threshold along the duration of the drought in unit volume is called the deficit volume (seen in Fig. 5).

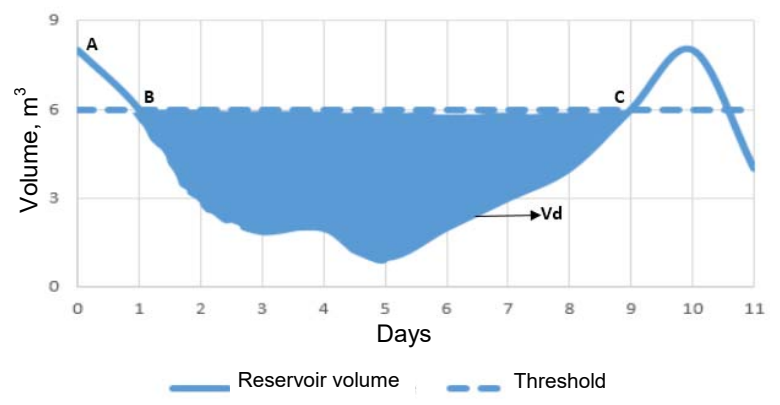

Fig. 5. Characteristics of hydrological drought; $\mathrm{B}-\mathrm{C}=$ drought duration; $V_{d}=$ drought deficit volume; source: own elaboration

\section{HYDROLOGICAL DROUGHT INDEX}

The hydrological drought index was calculated using the concept of water balance in the reservoir that is the relation between inflow, outflow, and change in storage at the same time. Inflow is the water in the reservoir that comes from the river and precipitation while outflow is the water in the reservoir that comes in the form of irrigation water coming out from the reservoir. The hydrological drought index is a deficit of the water volume of the reservoir under normal water reservoir conditions.

$$
I-O=\Delta S,
$$

Where $I=$ inflow $\left(\mathrm{m}^{3}\right), O=$ outflow $\left(\mathrm{m}^{3}\right)$, and $\Delta S=$ change of storage $\left(\mathrm{m}^{3}\right)$.

$$
R D I=\frac{V_{d}}{V_{e}},
$$

Where $R D I=$ reservoir drought index, $V_{d}=$ reservoir deficit $\left(\mathrm{m}^{3}\right), V_{e}=$ reservoir effective $\left(\mathrm{m}^{3}\right)$

\section{RESULTS AND DISCUSSION}

\section{TESTING DATA HOMOGENEITY}

Tests of data homogeneity were performed on daily reservoir volume data in the year of El-Nino. The $F$-test was conducted using Minitab-16 statistical software. It was found that all $P$-values less than $\alpha_{0.05}$ indicated the homogeneity of data, as shown in Table 2. 
Table 2. Test the homogeneity of reservoir volume at the time of El-Nino

\begin{tabular}{|c|c|c|c|c|}
\hline Year & Ratio of $S D$ & $\begin{array}{c}\text { Ratio of } \\
\text { variance }\end{array}$ & $F$-test & $P_{\text {value }}$ \\
\hline 1990 & 0.762 & 0.580 & 0.580 & 0.001 \\
\hline 1991 & 0.673 & 0.453 & 0.045 & 0.001 \\
\hline 1994 & 1.357 & 1.841 & 1.840 & 0.000 \\
\hline 2002 & 0.561 & 0.315 & 0.320 & 0.001 \\
\hline 2003 & 0.593 & 0.353 & 0.350 & 0.000 \\
\hline 2004 & 0.806 & 0.199 & 0.650 & 0.004 \\
\hline 2005 & 0.878 & 0.199 & 0.770 & 0.081 \\
\hline 2006 & 0.360 & 0.130 & 0.130 & 0.000 \\
\hline 2007 & 1.360 & 1.849 & 1.850 & 0.000 \\
\hline 2009 & 0.384 & 0.148 & 0.150 & 0.000 \\
\hline 2015 & 1.097 & 1.204 & 1.200 & 0.212 \\
\hline 2016 & 0.446 & 0.199 & 0.200 & 0.000 \\
\hline
\end{tabular}

Source: own study.

\section{FLUCTUATION OF RESERVOIR CAPACITY}

The weak El-Nino events occurred in 1994, 2004, 2005, 2006, and 2007. Although these events were classified as weak, they had a significant impact on the reservoir volume. A decrease in the reservoir storage occurs simultaneously and never reached the effective capacity over a long time period, as shown in Figure 6. The largest decrease in the reservoir volume occurred in December at the value of $16.01 \cdot 10^{6} \mathrm{~m}^{3}$. The reservoir can still provide water because inflow from the river is still available. The weak El-Nino pattern showed a similar trend from every year. The reservoir volume is reduced extremely for only 4 months but does not interfere with the operation of the reservoir.

In the case of moderate El-Nino events (Fig 7), the changes in reservoir volume are more extreme than in the weak El-Nino event. The extreme decrease is, more or less, between $120^{\text {th }}$ and $240^{\text {th }}$ day. After this period, the deficit is very serious. In this event, the volume of the reservoir is always below effective volume, although it does not exceed the minimum storage. The reservoir deficit volume from the effectiveness limit reaches $16.67 \cdot 10^{6} \mathrm{~m}^{3}$, thus almost every El-Nino event occurs. The pattern of occurrence of moderate El-Nino shows the same pattern both in terms of time and reduction of reservoir volume. It was also identified that moderate El-Nino were accrued 5 times, which is in 1991, 1992, 2002, 2003, and 2009.

The strong El-Nino event occurred in the period of 1982-1983, 1997-1998, and 2015. The impact of El-Nino has caused a very extreme deficit in reservoir volume. During the occurrence of El-Nino, the water volume of the reservoir is under the effective volume of the reservoir. In 1983 and 2015, the deficit of reservoirs reached the minimum reservoir or dead stor- age. The maximum deficit of the reservoir from the effective crater is $21 \cdot 10^{6} \mathrm{~m}^{3}$. The decreasing rate of the reservoir volume is quite high with a long period of 9 months (Fig. 8). If the El-Nino occurs in the following years, it will impact the occurrence of drought and will affect the structure of the reservoir.

\section{DECREASING OF DROUGHT LINE}

The decrease in the reservoir volume was found to drastically decrease for the 6-9 months period. It may continue if El-Nino event occurs in the following year. The decrease in the reservoir volume at the time of El-Nino starts in March and ends in November. The decrease in reservoir volume at the most extreme El-Nino reaches $3.97 \cdot 10^{6} \mathrm{~m}^{3}$, almost reaching the dead storage and deficit average of $9.27 \cdot 10^{6} \mathrm{~m}^{3}$ per day (Fig. 9). The function of the water reservoir decrease is the relationship between the volumes of water capacity decrease $\left(V_{d}\right)$ with the length of time the water reservoir decreases $(t)$.

\section{INCREASING OF DROUGHT LINE}

Figure 10 shows that the average time of water increase is 2 months with a maximum volume of $21.06 \cdot 10^{6} \mathrm{~m}^{3}$ and daily average is $7.61 \cdot 10^{6} \mathrm{~m}^{3}$. The increase in the reservoir volume can be attributed to the water coming from river flows and rainfall. This filling indicates that El-Nino's event is beginning to end and the reservoir is beginning to fill. Refuelling of the reservoir water occurs slowly because the inflow is still small and the outflow is large. Achieving the effective recharge takes a long time and a big inflow. The function of the water reservoir increase is the relationship between the volumes of water capacity increase $\left(V_{i}\right)$ with the length of time the water reservoir decreases $(t)$.

\section{HYDROLOGICAL DROUGHT INDEX}

Figure 11 shows that the hydrological drought occurring in Batujai dam showed a pretty similar trend depended on the occurred of El-Nino. The water volume deficit varies depending on the El-Nino type. When El-Nino is very strong, drought index indicates very severe drought with long duration of time. The hydrological drought index reached -0.89 when the water level of the reservoir is 87.00 above the sea level (Tab. 3). The volume of the reservoir at that time is only $2.48 \cdot 10^{6} \mathrm{~m}^{3}$ below the dead volume of the reservoir $\left(3.1 \cdot 10^{6} \mathrm{~m}^{3}\right)$. Based on the drought index value, the criteria of drought hydrological index in Batujai dam are divided into 4 criteria [NOAA 2017], which are weak, moderate, severe, and extreme. 


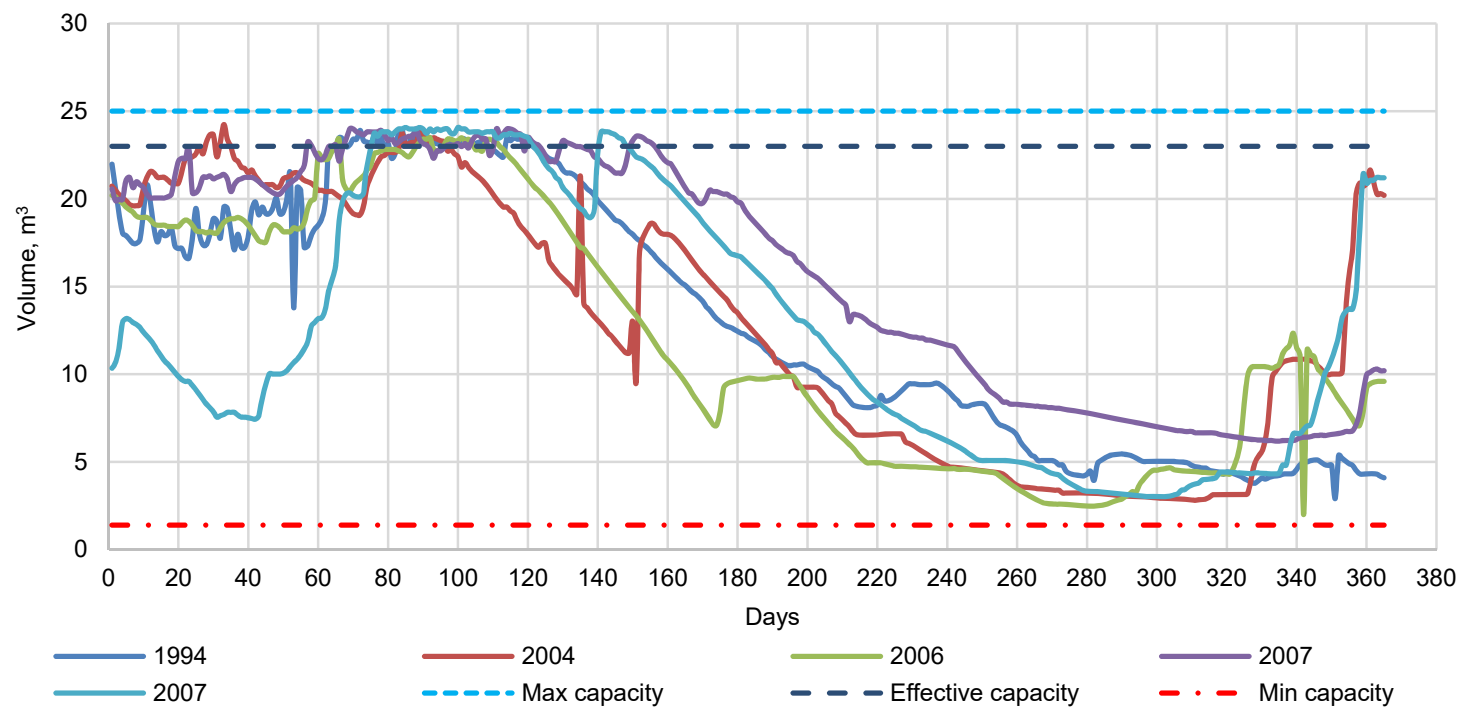

Fig. 6 . The capacity deficit of the reservoir at the time of weak El-Nino; source: own study

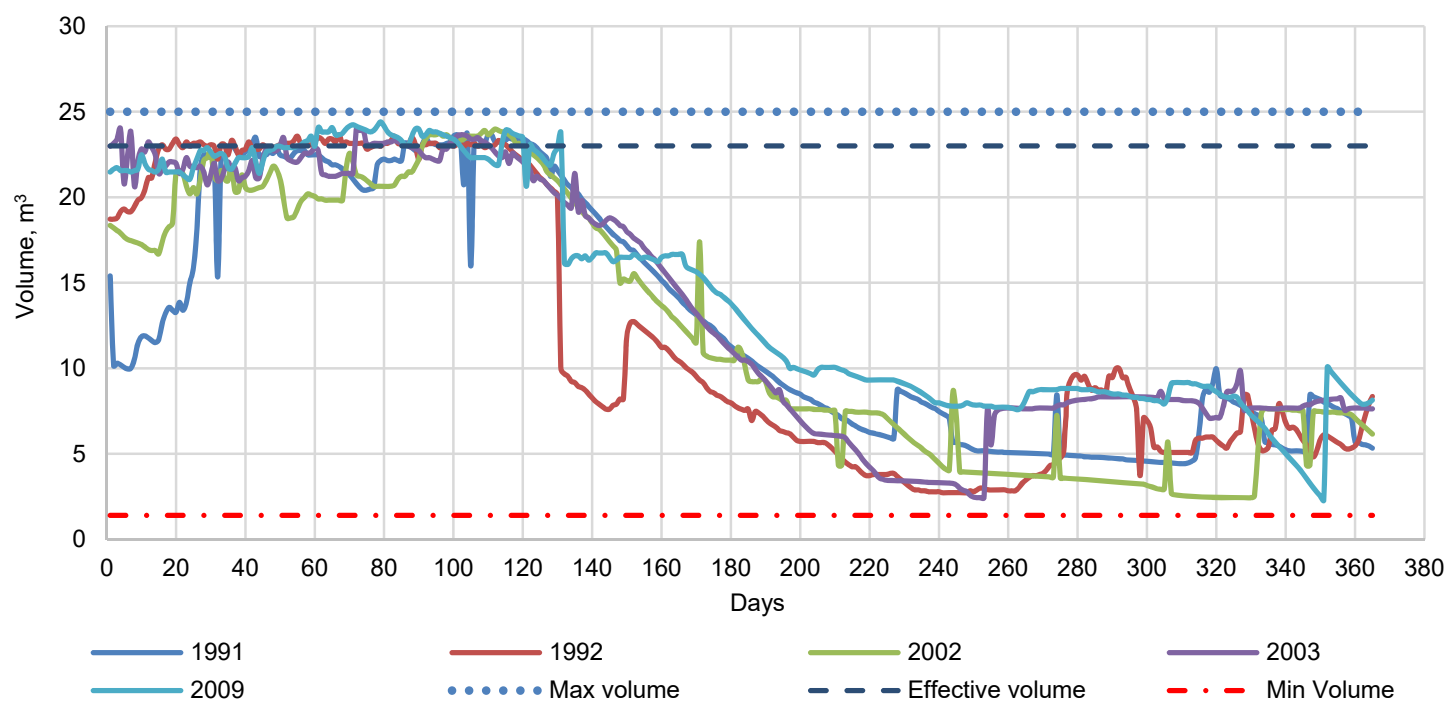

Fig. 7. The capacity deficit of the reservoir at the time of moderate El-Nino; source: own study

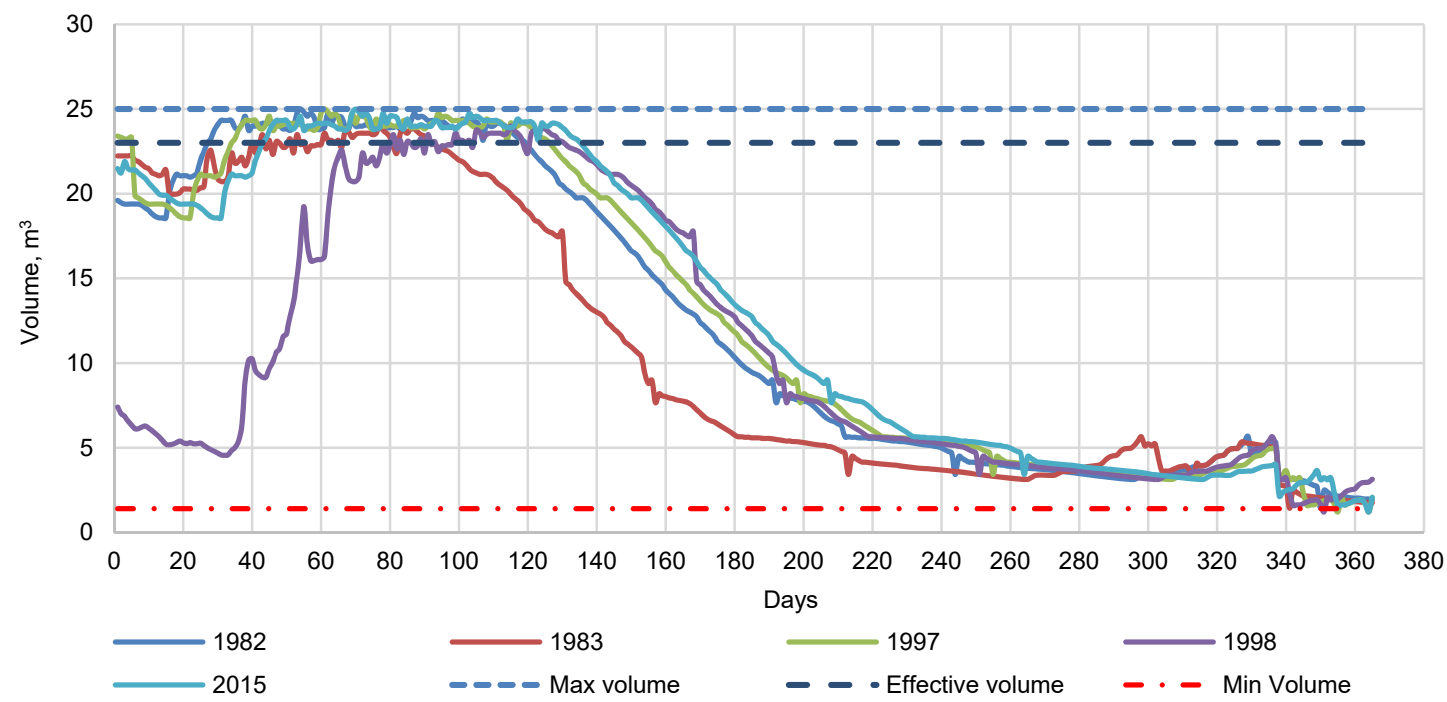

Fig. 8. The capacity deficit of the reservoir at the time of very strong El-Nino; source: own study 


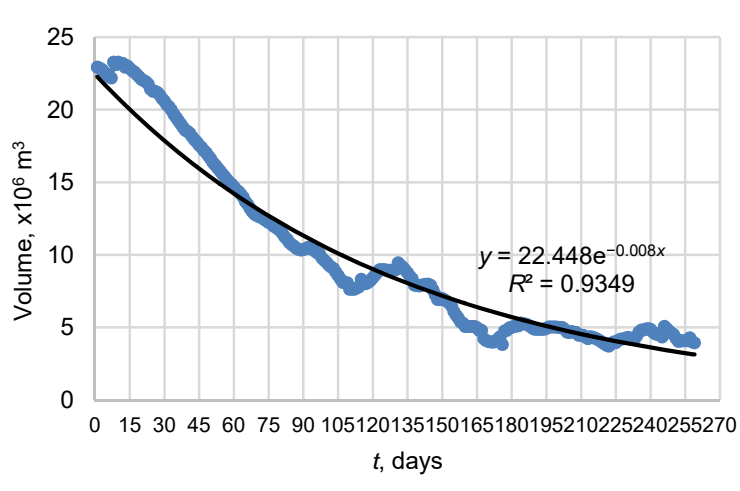

Fig. 9. Decreasing of drought line; source: own study

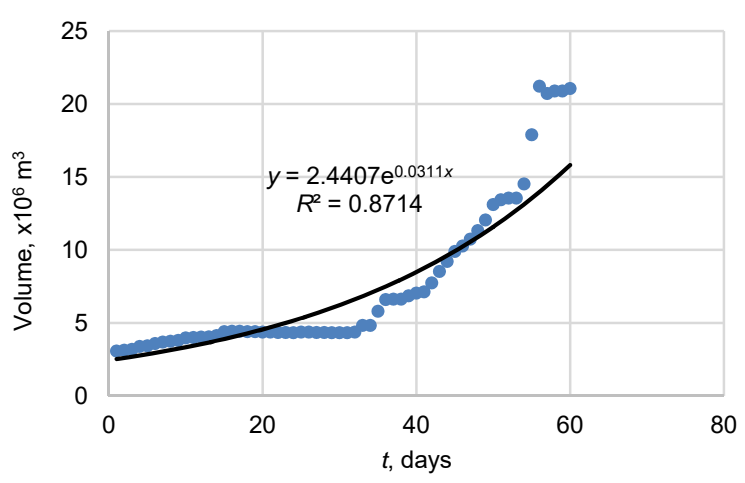

Fig. 10. Increasing of drought line; source: own study

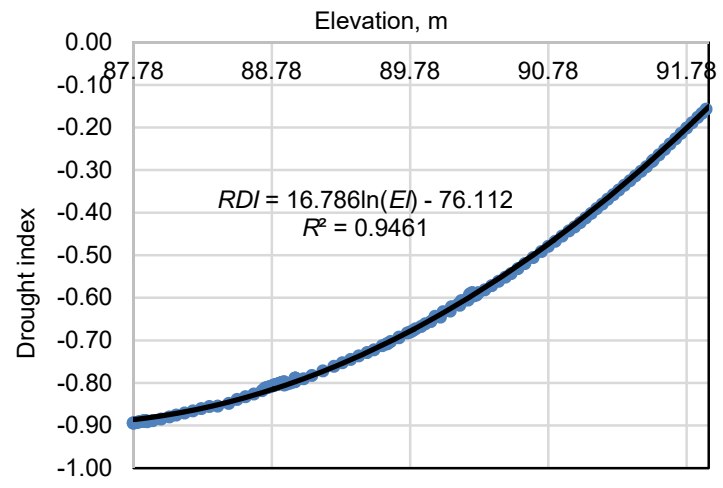

Fig. 11. Relation of the hydrological drought index to the water level of the reservoir; source: own study

Table 3. Hydrological drought index Batujai dam

\begin{tabular}{|c|c|c|}
\hline $\begin{array}{c}\text { Water level } \\
\text { elevation, } \mathrm{m}\end{array}$ & $\begin{array}{c}\text { Hydrological drought } \\
\text { index }\end{array}$ & $\begin{array}{c}\text { Drought } \\
\text { Description }\end{array}$ \\
\hline $87.78-88.92$ & $-0.89 \leq R D I<-0.80$ & extreme drought \\
\hline $88.92-90.06$ & $-0.80 \leq R D I<-0.59$ & severe drought \\
\hline $90.06-91.19$ & $-0.59 \leq R D I<-0.46$ & moderate drought \\
\hline $91.19-92.33$ & $-0.46 \leq R D I<-0.01$ & weak drought \\
\hline
\end{tabular}

Source: own study.

\section{CONCLUSIONS}

The change in reservoir volume can be directly related to the regions water resources condition. The use of reservoir volume as a tool for monitoring climate change is appropriate because the parameters used are very measurable. El-Nino events greatly af- fect the availability of water in the reservoir. The reservoir volume decreases significantly in comparison with the effective capacity, reaching the minimum capacity of $2.48 \times 10^{6} \mathrm{~m}^{3}$. The average decrease in the reservoir capacity takes very long, which is approximately between $120^{\text {th }}$ and $240^{\text {th }}$ days. The duration of drought can be very rapid and may last for almost nine months from February to November. The hydrological drought index reaches -0.89 when the reservoir water level is 87.00 above the sea water level. Based on the El-Nino criteria, the hydrological drought index with water reservoir consists of 4 types, which are weak ( $R D I$ from -0.46 to -0.01$)$, moderate drought ( $R D I$ from -0.59 to -0.46$)$, severe drought (RDI from -0.80 to -0.59$)$, and extreme ( $R D I$ from -0.89 to -0.80$)$.

\section{REFERENCES}

CALVER A. 2011. UK. WMO/ISDR Expert Group Meeting on Hydrological Drought Indices. Geneva 1-2 September 2011 p. 1-18.

FLEIG A. 2004. Hydrological drought-A comparative study using daily discharge series from around the world. Freiburg (DE). PhD Thesis. Albert-Ludwigs-Universität p. 7-24.

Fleig A., Tallaksen L., M., Hisdal H., Demunth S. 2006. A global evaluation of streamflow drought characteristics. Hydrololgy Earth System Sciences. Vol. 10 p. 535-552.

HAFER B.A. Dezman L.E. 1982. Development of a Surface Water Supply Index (SWSI) to assess the severity of drought conditions in snowpack runoff areas. In: Proceedings of the (50th) 1982 Annual Western Snow Conference Fort Collins, CO. Colorado State University p. 164-175.

Haro D., Abel S., Javier V., Joaquin A. 2014. Methodology for drought risk assessment in within-year regulated reservoir systems. Application to the Orbigo River system (Spain). Water Resources Management. Vol. 28. Iss. 11 p. 3801-3814. DOI 10.1007/s11269-014-0710-3.

Khezazna A., Amarchi H., Derdous O., BousaKhria F. 2017. Drought monitoring in the Seybouse basin (Algeria) over the last decades. Journal of Water and Land Development. No. 33 p. 79-88. DOI 10.1515/jwld20170022.

ŁABĘDZKI L., BĄK B. 2017. Impact of meteorological drought on crop water deficit and crop yield reduction in Polish agriculture. Journal of Water and Land Development. No. 34 p. 181-190. DOI 10.1515/jwld20170052.

Mishra A.K, Singh V.P. 2010. A review of drought concepts. Journal of Hydrology. Vol. 391. Iss. 1-2 p. 202216.

NOAA 2017. El-Nino and La-Nina years and intensities based on Oceanic Nino Index (ONI) [online]. [3.04.2017]. Available at: htpp//ggweather.com.enso/ oni.htm

PALMER W.C. 1965. Meteorological drought. Washington, DC. US Departement of Commerce. Research Paper. No. 45 pp. 58.

Panagiotis A., Fotios M., Nikos K., Vlasions H. 2012. Computation of Drought index SPI with alternative distribution functions. Water Resources Management. Vol. 26 p. 2453-2473. DOI 10.1007/s 11269-012-0026-0. 
Pandey R.P., Mishra S.K., Singh R., Ramasastri K.S. 2008. Streamflow drought severity analysis of Betwa River System (India). Water Resources Management. Vol. 22 p. 1127-1141.

Peters E., Bier G., Van Lanen H.A.J., Torfs P.J.J.F. 2006. Propagation and spatial distribution of drought in a groundwater catchment. Journal of Hydrology. Vol. 321. Iss. 1-4 p. 257-275.

TABARI H., JAEFAR N.P., ZADEH H.T. 2013. Hydrological drought assessment in northwestern Iran based on Streamflow Drought Index $(S D I)$. Water Resources Management. Vol. 27 p. 137-151. DOI 10.1007/ s11269-012-0173-3.

TAllaKSEN L.M., VAN LANEN H.A.J. (eds.) 2004. Hydrological drought - Processes and estimation methods for streamflow and groundwater. Vol. 48. Developments in water sciences. Elsevier Science BV, the Netherlands. ISBN 9780444517678 pp. 579.

Tsakiris G., Pangalou D., VAngelis H. 2007. Regional drought assessment based on the reconnaissance drought index $(R D I)$. Water Resources Management. Vol. 21 p. 821-833. DOI 10.1007/s11269-006-9105-4.

VAN LOON A.F., VAN LANEN H.A.J. 2012. Process-based typology of hydrological drought. Hydrology and Earth System Sciences. Vol. 16 p. 1915-1946.

VASILIADES L., LoukAS A., Liberis N. 2011. A water balance derived drought index for Pinios River Basin, Greece. Water Resources Management. Vol. 25 p. 1087-1101.
Wambua R.M., Mutua B.M., Raude J.M. 2015. Hydrological drought frequency estimation using stream flow drought index and modified Gumbel method in Upper Tana River Basin. International Journal of Current Research and Review. Vol. 7. Iss. 22 p. 42-51.

Xiaomang L., Wenhua L., Xia J. 2012. Comparison of the streamflow sensitivity to aridity index between the Danjiangkou Reservoir basin and Miyun Reservoir basin, China. Theoretical and Applied Climatolology. Vol. 111. Iss. 3-4 p. 683-691.

YAN D., Shi X., Yang Z., Li Y., ZaO K., YuAN Y. 2013. Modified Palmer drought severity index based on distributed hydrological simulation [online]. Mathematical Problems in Engineering. Vol. 2013. Article ID 327374 pp. 8. DOI 10.1155/2013/327374. [Access 9.10.2017]. Available at: https://www.hindawi.com/journals/mpe/ 2013/327374/

YANG W. 2010. Drought analysis under climate change by application of drought indices and copulas. MSc Thesis. Portland. Portland State University p. 11-12.

YeVJEVICH V. 1967. An objective approach to definitions and investigations of continental hydrologic droughts. Colorado State University, Fort Collins, Colorado. Hydrology papers. No. 23 pp. 18.

ZHANG R.P.S., CHEN X., ZHANG Z. 2014. Evolution of hydrological drought under the regulation of two reservoirs in the headwater basin of the Huaihe River, China. Stochastic Environmental Research Risk Assessment. Vol. 29. Iss. 2 p. 487-499.

\section{Wayan YASA, Mohammad BISRI, Moch SHOLICHIN, Ussy ANDAWAYANTI}

\section{Wskaźnik suszy hydrologicznej obliczany na podstawie pojemności zbiornika - przypadek zapory Batujai na wyspie Lombok, West Nusa Tenggara w Indonezji}

\section{STRESZCZENIE}

Analiza wskaźnika suszy hydrologicznej ma szerokie zastosowanie w zarządzaniu zasobami wodnymi. Na ubogiej w wodę wyspie Lombok wskaźnik suszy powinien być określany na podstawie analizy mierzalnych danych. Przedstawione w niniejszej pracy badania miały na celu ustalenie wskaźnika dla wyspy z wykorzystaniem zmian pojemności zbiornika. Podstawą analiz były dane o zbiorniku, szczególnie podczas wystąpień El-Niño. Głównymi parametrami analizowanymi w tej pracy były: homogeniczność danych, linia spadku objętości zbiornika, linia wzrostu objętości zbiornika, deficyt objętości zbiornika i wskaźnik suszy hydrologicznej $(R D I)$. Podstawowe równanie ujmuje bilans wody w zbiorniku, tzn. dopływ, odpływ i zmiany objętości. Wyniki analiz wskazują, że w trakcie trwania El-Niño wskaźnik suszy hydrologicznej przyjmował różne wartości w zależności od poziomu wody w zbiorniku. Kryteria natężenia suszy były następujące: słaba susza $-R D I$ od $-0,46$ do $-0,01$, gdy poziom wody w zbiorniku wynosił od 90,88 do $92,33 \mathrm{~m}$ n.p.m., umiarkowana susza $-R D I$ od $-0,59$ do $-0,46$, gdy poziom wody od 90,27 do $90,88 \mathrm{~m}$ n.p.m., silna susza $-R D I$ od $-0,80$ do $-0,59$, gdy poziom wody od 88,83 do 90,27 m n.p.m. i bardzo silna susza $-R D I$ od $-0,89$ do -0.80 , gdy poziom wody od 87,78 do $88,83 \mathrm{~m}$ n.p.m. Susza w trakcie bardzo silnego El-Niño trwała 9 miesięcy od lutego do listopada.

Słowa kluczowe: doptyw, El-Niño, odplyw, susza, wskaźnik suszy hydrologicznej, zbiornik 